\title{
Craftsmen Perception of the Dual Apprenticeship in Benin
}

\author{
Rubain Adéyèmi Bankolé (Corresponding author) \\ Faculty of Agronomy, University of Parakou, P.O. Box 123, Republic of Benin \\ E-mail: rubainbankole@yahoo.fr
}

Guy Sourou Nouatin

Faculty of Agronomy, University of Parakou, P.O. Box 123, Republic of Benin

Received: Nov. 3, 2020 Accepted: Dec. 5, 2020 Published: Dec. 31, 2020

doi:10.5296/ijssr.v9i1.17905 URL: http://dx.doi.org/10.5296/ijssr.v9i1.17905

\begin{abstract}
This paper analyzes the craftsmen perception of dual apprenticeship in Benin. The introduction of dual apprenticeship in technical vocational education and training system has established new structural arrangements in the apprenticeship system. The apprentices must leave the workshop for one day of theoretical instructions and practical knowledge. By assessing how this alternative system of apprenticeship is perceived, this research adopted a qualitative method. It was conducted in Cotonou, Abomey-Calavi and Parakou with the collaboration of the master craftsmen including staff members of professional associations, apprentices, trainers and heads of the vocational training centers. Purposive sampling and snowball sampling technique were applied to select them. In total, 66 participants have been interviewed. Data collection was carried out through life-history and individual semi-structured interview. Among the adopter categories, the research identified another category called business users to describe the training centers that recruit their apprentices. Apprentices who participate in the program are motivated by curiosity and by explicit knowledge from vocational training centers. Master craftsmen are satisfied with the program because of the formal certificates given to the apprentices after the training completion.
\end{abstract}

Keywords: dual apprenticeship, innovation, certificate of professional qualification, adopters' categories, motivation, satisfaction, Benin 


\section{Introduction}

Reforms in the apprenticeship system in most of sub-Sahara African countries have been developed in the last three decades. These reforms involve skills development in the informal sector (Adams, de Silva, \& Razmara, 2013) and the modernization of the traditional apprenticeship (Sonnenberg, 2012). This modernization takes into account the specificity and the nature of different categories of informal traders (Lesser \& Moisé-Leeman, 2009). Thereby, the adaptation of the reforms to the specific context is important for its success. In Benin, the reforms of the apprenticeship system were undertaken in 2005 with the technical and financial supports from donor agencies (Davodoun, 2011). These reforms involve the accreditation of the apprenticeship system as a component of the technical vocational education and training (TVET) system throughout the apprenticeship act 117/2005.

The Benin TVET system comprises TVET offered in secondary educational programs, TVET provided in tertiary education and apprenticeship programs. Apprenticeship has been implementing for several years in the informal sector through on-the-job training. The estimated number of youths in traditional apprenticeship is 800,000 (Davodoun, 2014), compared to the number of students in technical secondary school cycle 1 and 2 which, is estimated at 22,098 (MESTFP, 2016). That implies that many young people are enrolled in traditional apprenticeship. According to Walther (2008), the traditional apprenticeship is characterized by some gaps such as the unstructured of the skills learning and the commercial relationship between master and apprentice. In this regard, the reforms introduced by the Benin government aim first, to restructure the apprenticeship and second, to improve the quality of work and thus the income of youth (MEA, 2014). Throughout the reforms, two accredited programs were introduced: dual apprenticeship program which leads apprentices to the certification of professional qualification (Certificat de Qualification Professionnelle-CQP) and upgraded informal apprenticeship that is provided by master craftsmen followed by a national examination organized for apprentices who complete their apprenticeship schemes to receive another formal certificate, the certification of occupation qualification (Certificat de Qualification aux Métiers - CQM). Between both programs, dual apprenticeship involves innovative practices since it is a successful model derived from German's dual system which combines vocational education at schools and work-based training in companies. The introduction of the dual system has been adapted to Benin context with the combination of vocational education in the training centers and work-based training in the master workshops (Davodoun, 2011). The existing literature on the Benin dual apprenticeship, (David-Gnahoui \& Ahouangnivo, 2017; Bankolé \& Nouatin, 2020) reported the program by reviewing the discrepancies. Some authors described the roles of TVET actors/institutions in its implementation and the financing mechanism (Bankolé, Nouatin, \& Gandonou, 2019; Atindehou, 2013). But how do master craftsmen perceive the innovation of dual apprenticeship in the Benin crafts sector? This research states that the satisfaction and motivation of the master craftsmen and apprentices influence their perception of the dual apprenticeship program.

The research considers the dual system as an innovation introduced in the apprenticeship system due to its principles of duality and the primacy of the occupation that involves the 
commitment of the master craftsmen. In the adoption and diffusion of innovation, Rogers (1983), asserts that individuals' perceptions of the characteristics of innovations predict their adoption. Thereby, the perceptions of beneficiaries are very important to understand the adoption of an innovation. In order to know whether master craftsmen are satisfied with the dual apprenticeship, the research assessed the craftsmen perception of the program. The research also reviewed the motivation sources of the apprentices to participate in this dual system. Hence, the objective of this paper is to analyze the masters' perception of dual apprenticeship or CQP program.

To achieve this objective, we classified the categories of adopters among craftsmen who have participated in the dual apprenticeship since 2005 and studied the communication strategies used for enhancing craftsmen involvement in the program. Besides, we analyzed the relative advantages of master craftsmen and the motivation of the apprentices to participate in vocational education in the training centers.

\section{Method}

To conduct this research, the qualitative method has been used to collected and to analyze data. The participants are selected from three districts: Cotonou and Abomey-Calavi in Southern Benin and Parakou in Northern Benin. We selected Cotonou and Abomey-Calavi because most of the TVET institutions involved in the implementation of dual apprenticeship are located in these neighborhood districts. There, we interviewed more officials from the professional associations in those two zones of the research field. As far as Parakou is concerned, it has been selected because it is one of the biggest and cosmopolite cities in the Northern Benin. We have interviewed more master craftsmen and apprentices in this area. Those three were selected to vary the balance information across regions. The observation units comprise master craftsmen including staff members of professional associations, apprentices, trainers and heads of the vocational training centers. The participants' selection has been done using purposive and snowball sampling techniques. A total of 66 participants have been interviewed (see Table 1). Data collection was carried out through life-history and individual semi-structured interview. The most important items of the guideline are about the knowledge of dual apprenticeship, the process of its introduction and diffusion in the apprenticeship system, the relative advantages, the satisfaction of the craftsmen, the motivation of the apprentices to participate in the program. We applied content analysis and descriptive statistics to analyze data. 
Table 1. Number of respondents per category

\begin{tabular}{ll}
\hline Category & Number of participants \\
\hline Master craftsmen & 24 \\
Apprentices & 30 \\
Trainers/VTC & 7 \\
Heads of VTC & 5 \\
Total & 66 \\
\hline
\end{tabular}

To highlight the master craftsmen of the innovation of dual apprenticeship, we built an analytical framework based on the adoption and diffusion of an innovation theory by Rogers (1983, see Figure 1).

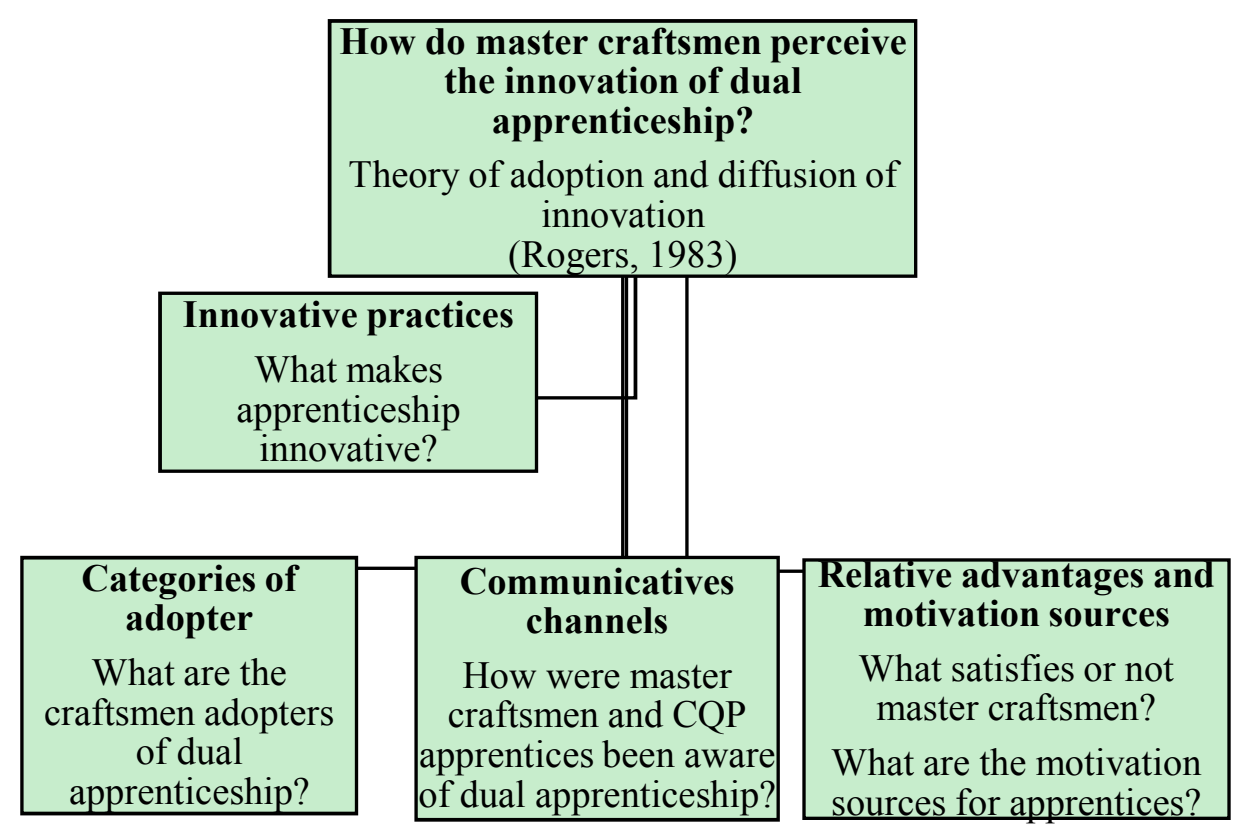

Figure 1. Analytical framework of craftsmen perception of dual apprenticeship

Through the Figure 1, we first, state that craftsmen perception of dual apprenticeship must start with the identification of the innovative practices in the apprenticeship system. Hereby, the question is "what makes innovative dual apprenticeship?". Innovative practices introduced in traditional apprenticeship through the dual system are: the duality of the training and the certification of the program. Secondly, we assume that master craftsmen have been differently involved in the program. In this regard, the classification of adopters contributes to a full understanding of the process of the introduction of the dual system in traditional apprenticeship. Thirdly, the communication channels used are very important to capture the diffusion among craftsmen. And fourthly, we considered the relative advantages 
for master craftsmen and the motivation sources of the apprentices to participate in the training program.

\section{Results}

\subsection{Adopter Categories and Mobilization Strategies}

\subsubsection{Adopter Categories of the Dual Apprenticeship Program}

According to Rogers (1983), individuals adopt an innovation in a different time sequence. Hence, the author distinguishes five categories of adopters: innovators, early adopters, early majority, late majority and laggards. We matched each category to the adopters of dual apprenticeship in Benin. In addition to the five categories, the findings revealed another category that we named "business users".

Inventors include adopters who are excited to try new ideas; the author names them "venturesome". The communicative patterns and social networks through friendship are common linking among innovators. In the adoption of dual apprenticeship in the Benin apprenticeship system, inventors are craftsmen who participated in the curriculum design for the training.

Early adopters according to the classification of Rogers (1983) represent all integrated actors from a local social system. Some can be considered as leaders of a group and who can influence the innovation-decision. They play an important role in the diffusion process, promoting the adoption of innovation. In this regard, staff from professional associations at the local level are the main early adopters. They are in charge of mobilizing CQP candidates for the dual apprenticeship program. They have contributed to the enrolment stage of the apprentices before the entrance test. Hence, early adopters are members of the craftsmen's professional associations.

As far as early majority this category is concerned, it is similar to the early adopters because they interact with their peers. The difference is that the period of innovation-decision may be longer than the two other categories. Thereby, leaders from professional associations are still dominant and play a decisive role in the diffusion process.

Besides, late majority category adopts an innovation by the necessity to do so. They do not take risks to adopt an innovation. They adopt because everybody has adopted, thus the social pressure influences their positive response to innovation. In this study, it is found that other master craftsmen who are not members of professional associations are indicated.

Laggards are the latest category of adopters due to their disadvantaged position in the social system. They have no decision power to adopt an innovation. The decision to adopt an innovation is made by comparing what has been done in the traditional practices from what is the new ideas or new practices. In the research field, laggards are the master craftsmen who remain determined by the local custom.

Beyond these five categories, the findings have revealed an additional category which is called "business users". According to the articles 6 and 7 of decree 042/2005 on the 


\section{Macrothink}

introduction of dual apprenticeship in TVET system, public as well as private vocational training centers are the main institutions that can offer vocational education. The research revealed that the training centers recruit their apprentices to be enrolled for the CQP entrance test. We used the concept "business users" to name the category of the training centers that recruits their apprentices who apply for CQP entrance test. Regarding their position in the system as the owners of vocational training centers, either craftsmen or professionals or others, there are not adopters, they use the system to raise their business.

After discussing the categories of adopters, we identified the communication strategies used to bring awareness craftsmen and their associations.

\subsubsection{Mobilization Strategies for Dual Apprenticeship}

In order to lead master craftsmen to participate in the program, three main mobilization strategies have been used: social media mobilizations, awareness campaigns at national, regional and local levels, field visits conducted by the head of the vocational training centers.

Public institutions are responsible for the social media mobilization through television (TV) and radio sessions on public channels. This is sometimes supported by donor agencies sharing their experiences in the dual system. For examples, a film has produced in 2017 on the apprenticeship reforms, especially the dual system. By following the link in the end page (Note 1), you can watch that films. In the period from 2016 to 2018, the government did not recruit apprentices for the program. Before launching it in 2018, a TV session was produced and reported on the experience of Swiss dual system in the collaboration with a team from the University of Abomey-Calavi (UAC), University of Parakou (UP) and officials from the head of Department of Technical Vocational Education and Training (D-TVET), the National Confederation of Craftsmen (CNAB) and the Fund for Development of Continuing Vocational training and Apprenticeship (FODEFCA). The TV session is available through the link indicated in the end page (Note 2). In November 2018, the number of the CQP candidates for the entrance test has increased to 8,413 applicants. The following figure shows the enrolment of the apprentices for the entrance test: 


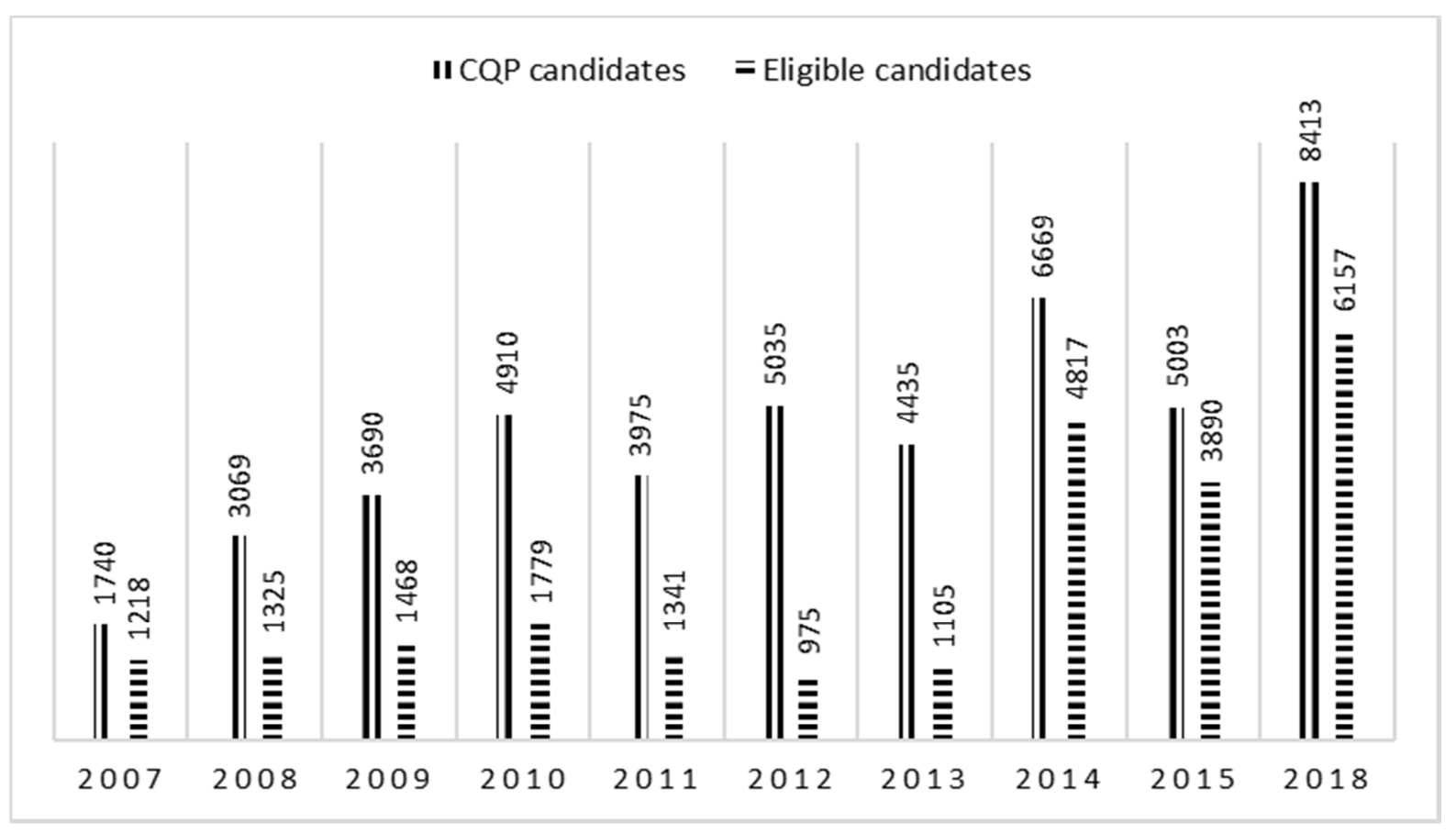

Figure 2. Progress of CQP candidates for entrance test 2007-2018

Source: Own depiction based on the data provided by D-TVET.

Figure 2 shows a gradual increase of the CQP candidates across the years with the highest number in 2018. However, the number has decreased with low enrolment for the entrance test in 2011, 2013 and 2015. This can be explained by the fact that in 2010, 2012 and 2014, the Benin government did not have enough financial resources to sponsor apprentices who achieved the average entrance test scores. Hence, in the following years i.e., 2011, 2013 and 2015, the number of apprentices has decreased.

In addition to the TV sessions, public institutions at national and regional levels proceed by radio sessions through the press releases. In 2020, the Benin government launched the recruitment of 1,000 young people for the dual apprenticeship. This public policy lies in the new strategy for TVET validated in September 2019. To increase the social mobilization for the participation of young people, a press release was undertaken by the D-TVET. In the 12 regions of the Republic of Benin, the public services for TVET also undertakes press releases.

Professional associations also contribute to the master craftsmen mobilization through the awareness campaign from national to regional and to local community levels. The staff of CNAB undertakes the awareness campaigns to the 80 associations (Collectifs des artisans) that exist in the 77 districts level. Professional associations at district level have to interact with those at the local level in order to share information among craftsmen. By developing a chain of information, professional associations work to make the dual apprenticeship program more attractive for craftsmen and their apprentices. 
"We held two awareness campaigns into nationwide in 2015. We did not attend all the regions but professional associations at the district and the local levels are still working to share information about the CQP program" (J. A. President of CNAB, Cotonou, 2018).

The quote from the president of CNAB illustrates the necessity of the collaboration with other associations and craftsmen to achieve the goal.

In contribution to the mobilization strategies, vocational training centers develop more field visits on the master craftsmen workshops to recruit many apprentices for the CQP entrance test. The discussion with one of the heads of vocational training centers revealed the evidence:

"The mobilization of apprentices for CQP application is entitled to the professional associations at district level. But later, we (training centers) also engage in the mobilization by visiting the craftsmen workshop in order to recruit more apprentices who will apply for the entrance test [...]" (Mrs. S. D. B. L., head of the training center, hairdresser, Parakou, 2019).

The quote shows how the role has progressed from professional associations to vocational training centers. The next section provides information about the satisfaction and motivation of craftsmen about the program.

\subsection{Introduction of the Dual System in the Traditional Apprenticeship: Relative Advantages and Motivation Sources}

\subsubsection{Relative Advantages for the Master Craftsmen}

The master craftsmen interviewed have a positive perception of the CQP program for two reasons. First, master craftsmen have well-perceived the dual apprenticeship program because of its formal accreditation that leads to the CQP certificate received by the CQP graduates. For them, this certificate is equivalent to the certificate of professional aptitude (Certificat d'Aptitudes Professional-CAP) which, is a first TVET graduation in secondary education. The following quotes illustrate the evidence:

"The CQP certificate is an important degree introduced in the apprenticeship system. It is currently the highest graduation that exists in the apprenticeship system. Many of my colleagues who graduated with the CQP certificate have been recruited in the public sector. Hence, the CQP certificate gives access to the public function" (B. A. CQP graduate, sewing cut, Parakou, 2020).

"Craftsmen were tended to be reluctant to participate in the program because it is addressed also to masters as well as apprentices. However, they were also eager to experiment the program whether it will fill some expectations such as the accreditation of traditional apprenticeship and the certification" (A. M. staff from a professional association, Parakou, 2019).

Second, the program is well-perceived because it has contributed to skills development. In the master craftsmen view, the program has led to the definition of the standards of the 
training and the skills qualification through the curriculum design.

Despite the positive perception of the CQP program, master craftsmen revealed three main limitations. First, the program is addressed to apprentices who completed the last two years of the primary education that corresponds to level 1 of the International Standards Classification of Education-ISCED (literacy and numeracy). This education level excludes the apprentices who do not achieve the literacy requirements to participate. Besides, the training providers from the training centers found that some CQP apprentices meet the literacy requirements but do not have adequate literacy and numeracy levels to achieve much knowledge. Second, the scholarship offered by FODEFCA is not sometimes enough to enroll many apprentices in various occupations in which the program is implemented. The amount of the scholarship offered in each occupation depends on the fund available and on the priorities of the government which also vary across the years. Thereby, the number of the scholarships is very low when there is low financial support from donors. This affects the implementation of the program that does not follow adequate planning as it exists for schools' programs. Third, the master craftsmen revealed that the governance and the management of dual apprenticeship are essentially held by public institutions. Hereby, the master craftsmen think that they are low involved. The following quotes state:

"It is the public institutions that are responsible for the management of the dual system from the recruitment phase to the implementation of the program and its certification. We are not involved in the definition of priorities of the government for the apprenticeship system" (M. S., Master craftsman, metallic construction, Cotonou, 2019).

"Our staff members of associations participate in the conferences in which they are invited. But I think that most of the government priorities for the apprenticeship system are not built in the collaboration with the private sector. Furthermore, the professional associations in crafts sector are not strong to persuade public officials during the meetings. Hence, we are not well involved in the decision-making for the apprenticeship system."

The quotes elucidate two related issues: the involvement scale of the business sector in the reforms carried out in the apprenticeship system and the robustness of the professional associations. Despite the participation of the staff members of professional associations in the reforms, master craftsmen found that their involvement must be improved.

We learnt about the relative advantages for craftsmen and some limitations as viewed by craftsmen. In the following subsection, we study the motivation of the apprentices to participate in the program.

\subsubsection{Motivation Sources for Participating in Dual Apprenticeship}

We interviewed $30 \mathrm{CQP}$ graduates and apprentices to know what are the motivation sources to participate in the vocational education offered by the training centers. First, we asked them the question "How did you know the about the dual apprenticeship program?" The figure presents the responses from the interviewees: 


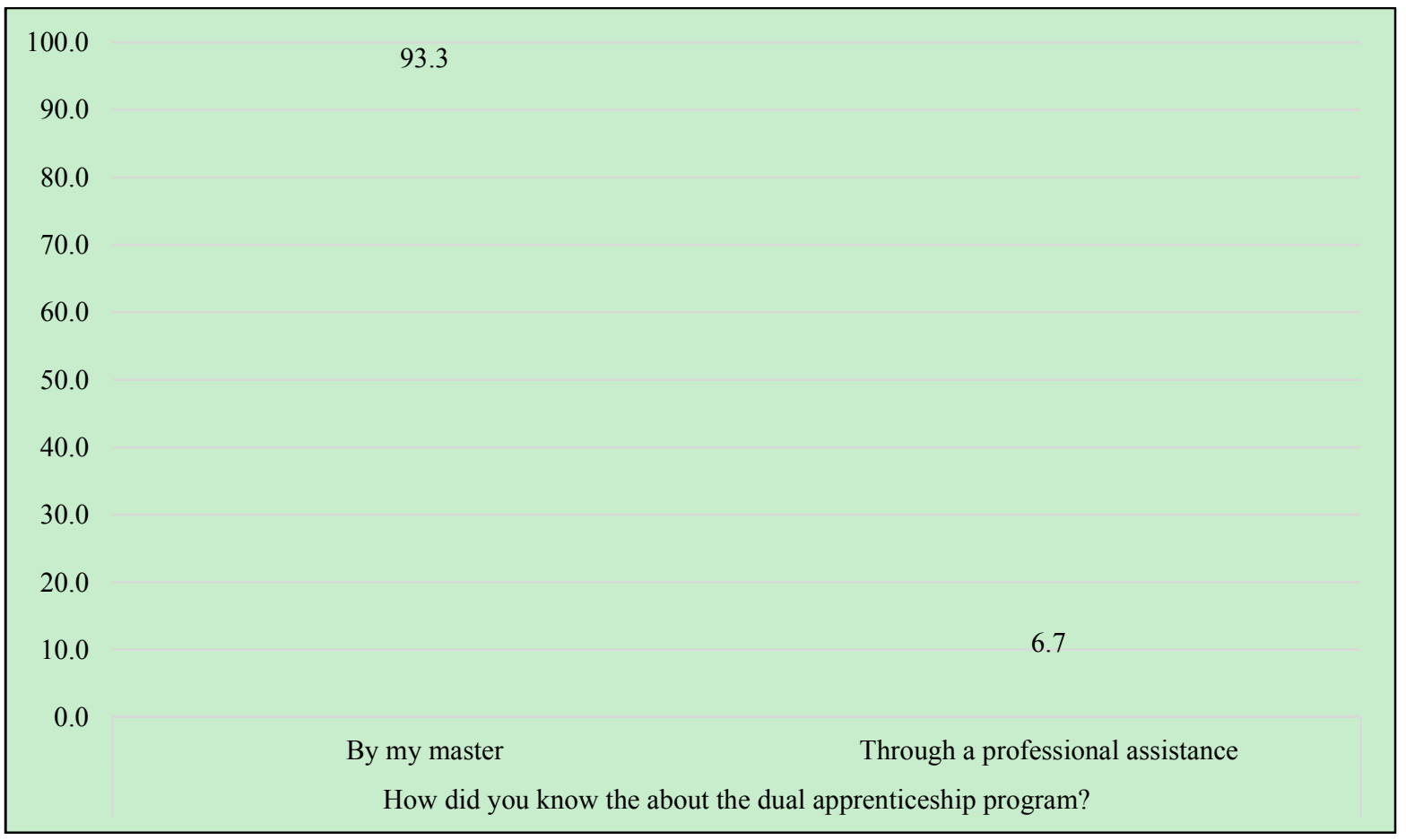

Figure 3. Sources of knowledge of dual apprenticeship

Figure 3 shows that most of the apprentices have known about the program through their master craftsmen. This result displays the evidence that the community-based mobilization strategies used, were essentially addressed to reach craftsmen through their professional associations. Thereby, apprentices have mostly access to information through their masters. Even though these strategies were used to reach an important number of craftsmen, the research field found that many craftsmen do not participate in the associations.

The research sought the motivation source of the CQP apprentices to participate in this dual system. We asked them the question: "What makes you motivated to take part in vocational education in the training centers?" 


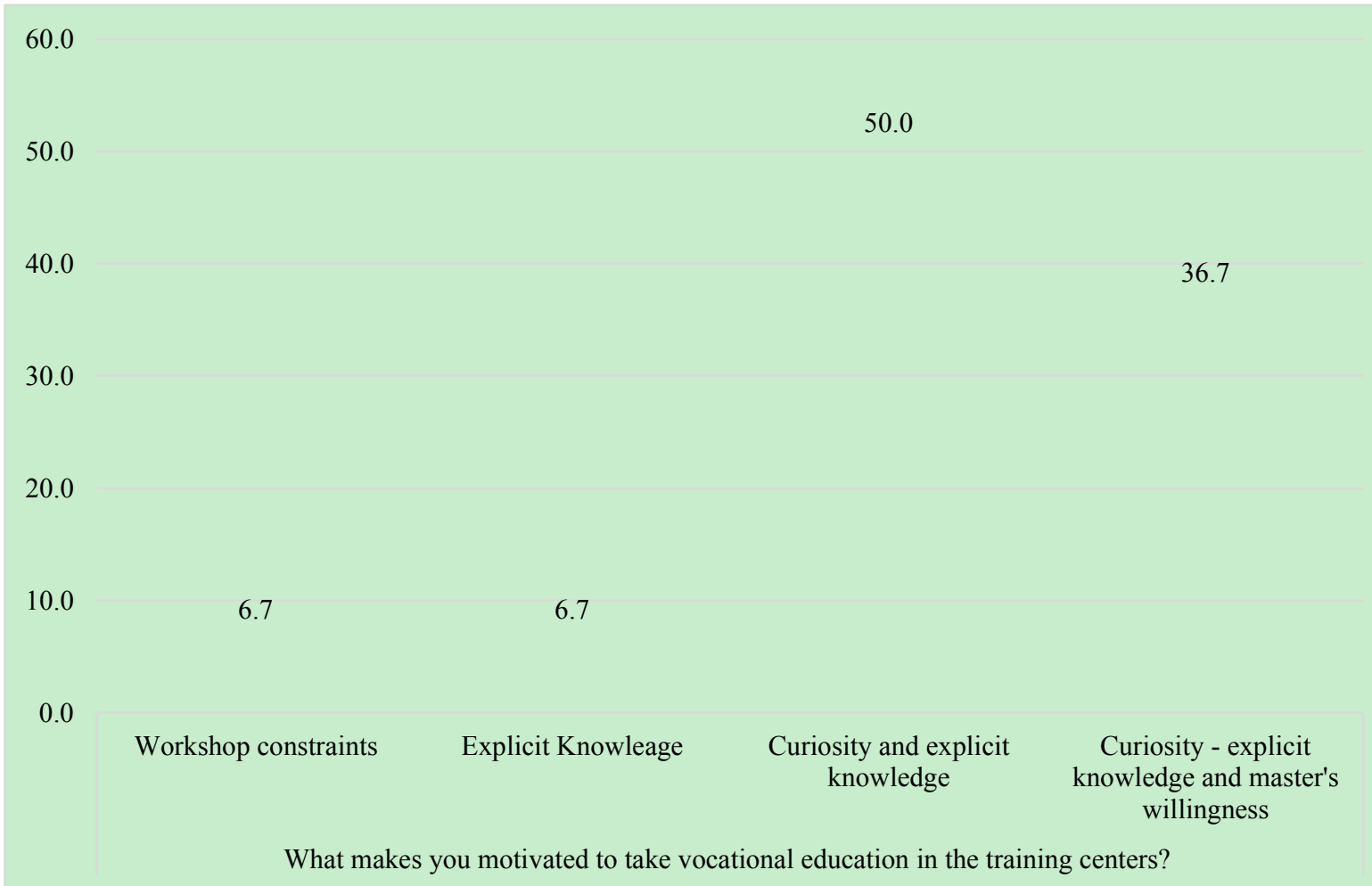

Figure 4. Motivation sources for CQP apprentices

The Figure 4 displays the importance of the modality "curiosity coupled with explicit knowledge". This modality was the most significant for 50 percent of CQP graduates interviewed. In the rest of the interviewees, 36.7 percent pointed out the modality "curiosity, explicit knowledge and master's willingness". Hence, the results on the motivation sources for apprentices have shown three important modalities: curiosity for knowledge, explicit knowledge and master's willingness to release apprentices for vocational education. The other modality that is not significant is the "workshop constraints". The workshop constraints mean that the work conditions are difficult for the apprentices. In this regard, we asked apprentices to know the relative advantages of vocational education received in the training centers (see Figure 5). 


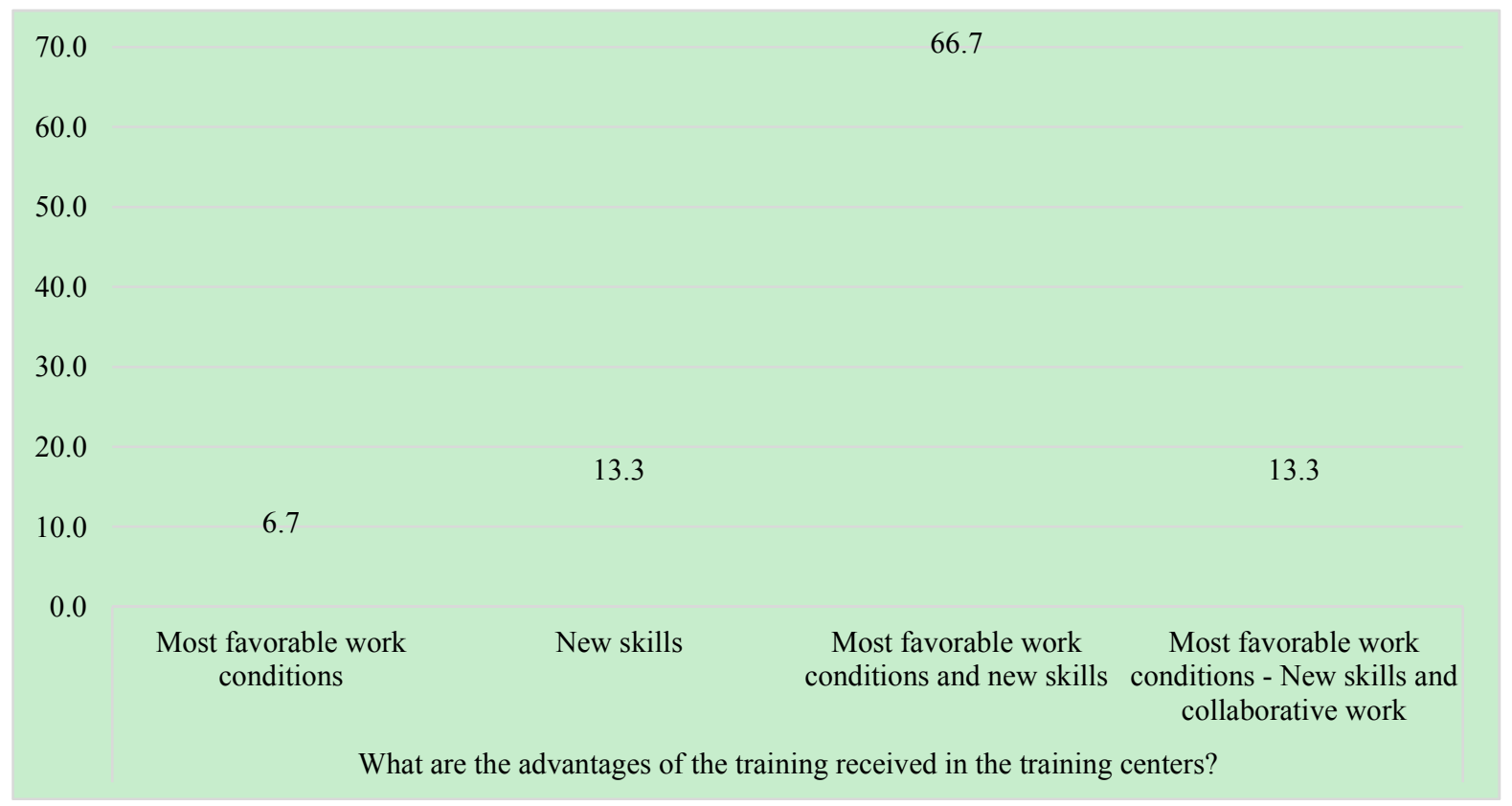

Figure 5. Relative advantages for CQP apprentices

The most significant response regarding the advantages CQP apprentices see about vocational education they receive in the training centers combines favorable work conditions and the new skills they earn. One of the CQP graduate asserts:

"I was very eager to discover what happens in the training centers; it is very interesting. We have been trained on how to use technical tools or materials with more practical sessions" (Mrs. E. A., CQP graduates, Parakou 2020).

The quote also underlines the importance of work conditions as a modality which includes the latest technology used for materials and equipment. The new skills refer to the competency that apprentices learn in the training centers.

\section{Discussion}

Based on our analytical framework, the analysis of the craftsmen perception of the dual system in apprenticeship figured out three major points in the process of diffusion: the strong influence of professional associations in the mobilization strategies, the formal accreditation of the program and the governance and management challenges.

In the mobilization process, social media, TV and radio session and press releases were the main channels used. However, the results revealed that professional associations at national, district and local levels have played an important role as they are committed to make craftsmen aware of the program. Moreover, since vocational training centers need to get a training contract with FODEFCA, they are also in the mobilization through field visits in workshops for the apprentices' recruitment. This situation shows that when craftsmen and their associations are committed to roles, they are likely to contribute to support the 
innovation.

The analysis of the relative advantages has led to the evidence that even though master craftsmen are reluctant to adopt the innovation, they also show their willingness to experiment the new approach. Dual apprenticeship leads young people with basic literacy and numeracy levels to earn a formal certificate (CQP certificate) while those apprentices with no prior education are not eligible. This result matches the findings by Sonnenberg (2012) in Senegal and Ghana where vulnerable and marginalized young people are excluded from the skills training programs. However, CQP certificate and curriculum development for the training are the important advantages in the view of the master craftsmen. Considering this, we can state that dual apprenticeship matches expectations for improving skills development in the crafts sector. The introduction of the program leads to the formal recognition of the skills learning in the informal sector and aims to upgrade traditional apprenticeship. For the CQP apprentices/graduates, the improvement of the learning conditions and the acquisition of new skills represent the key advantages. Hence, curiosity and the improving pedagogy of learning influence the motivation of the CQP apprentices/graduates. This result was supported by Walther (2008), who presented the evidence that the formal certificate CQP and the social validation of the craftsmen's competence are sources of motivation.

Apart from these positive aspects of the program, the research revealed that there is a great challenge with the robustness of the professional bodies that represent craftsmen in the program. The governance of the program, its management and financing are essentially held by public institutions and donors rather than public and private sectors share power and roles. A study by Cros et al. (2009) has already shown that curriculum reforms through the competence-based approach in Africa face challenges of management, planning and time management. In the same regard, David-Gnahoui and Akoute-Hounsinou (2015) highlighted the inefficacity of the financing model of dual apprenticeship in Benin. However, the robustness of the private institutions or business sector in the governance, management and financing of this dual apprenticeship is not studied. We also do not go in-depth regarding measuring the robustness of the private institutions because this requires specific method and tools.

\section{Conclusion}

Following the adopters' categorization, it is found that the innovators are craftsmen who have participated in the curriculum development. The early adopters include staff members of professional associations. Early majority and late majority adopters comprise master craftsmen members of a professional association, especially leaders from these associations. Laggards are those who remain connected to their traditional custom of the apprenticeship. Besides, the results revealed another category called business users. Business users' category is used to name vocational training centers that recruit their apprentices for the CQP entrance test to maximize their training contract with FODEFCA. Although the introduction of dual apprenticeship was supported more by donor agencies, this research showed that it has improved the traditional apprenticeship and its accreditation. There are the most two important points on which master craftsmen perceive well the program. CQP apprentices who 
participate in the program are motivated by curiosity and explicit knowledge. The literacy conditions to applying for CQP candidates exclude many young people with no basic formal education. Nevertheless, the results show that the governance of the program and its management are essentially held by public institutions whereas the financing is supported by donors.

\section{References}

Adams, A. A., de Silva, S. J., \& Razmara, S. (2013). Improving Skills Development in the Informal Sector. Washington: World Bank. https://doi.org/10.1596/978-0-8213-9968-2

Atindehou, G. O. (2013). La formation professionnelle par apprentissage de type dual au Benin: Le dispositif, les acteurs et le financement: Quel bilan? Mémoire de formation. Dakar: CESAG.

Bankolé, R. A., \& Nouatin, G. S. (2020). Dual apprenticeship in Benin: Between theory and practice. African Educational Research Journal, 8(1), 46-56. https://doi.org/10.30918/AERJ.81.19.054

Bankolé, R. A., Nouatin, S. G., \& Gandonou, E. (2019). The dual apprenticeship in Benin: Strategic actors and roles. In D. Amouzouvi (Ed.), Mélanges en l'honneur du Professeur Titulaire Emérite Albert J. NOUHOUAYI (pp. 537-558). Cotonou: Edition LARRED. doi:ISBN: 978-99982-0-229-0

Cros, F., de Ketele, J. M., Dembélé, M., Develay, M., Gauthier, R. F., Ghriss, N., ... Tehio, V. (2009). Étude sur les réformes curriculaires par l'approche par compétences en Afrique. Sèvre: Centre international d'études pédagogiques (CIEP).

David-Gnahoui, M. E., \& Ahouangnivo, T. (2017). Etude diagnostique participative et approfondie du dispositif de la formation professionnelle de type dual. Cotonou: Rapport final.

David-Gnahoui, M. E., \& Akoute-Hounsinou, M. F. (2015). Le financement comme défi à l'efficacité de la formation professionnelle par apprentissage de type dual au Bénin. Cahiers $d u \quad$ CBRST, 3(7), 755-776. Retrieved from https://bec.uac.bj/uploads/publication/53d7229a59566234b0eb9213fe781998.pdf

Davodoun, C. (2014). L'apprentissage des métiers artisanaux. (S. Editions, Ed.) Ateliers thématiques en préparation au deuxième Forum national de l'éducation. Choix de communications, 2, 525-566.

Davodoun, C. C. (2007). Artisanat au Bénin: Texte législatifs et règlementaires. Cotonou: Ruisseaux d'Afrique.

Davodoun, C. C. (2011). L'apprentissage de type dual dans l'artisanat au Bénin. Cotonou. Cotonou: Ruisseaux d'Afrique.

Lesser, C., \& Moisé-Leeman, E. (2009). Informal cross-border trade and trade facilitation reform in sub-Saharian Africa. OECD Trade Policy Working Paper, 86, 54. 
MEA. (2014). Rapport d'état du système éducatif. Dakar: IIPE-UNICEF.

MESTFP. (2016). Annuaire statistique 2014-2015. Cotonou: MESTFP-SGSI.

Rogers, E. (1983). Diffusion of innovations. New York: The Free Press.

Sonnenberg, K. (2012). Traditional Apprenticeship in Ghana and Senegal: Skills Development for Youth for the Informal Sector. Journal of International Cooperation in Education, 15(2), 93-105. Retrieved from https://home.hiroshima-u.ac.jp/ cice/wp-content/uploads/publications/15-2/15-2-06.pdf

Walther, R. (2008). Nouvelles formes d'apprentissage en Afrique de l'Ouest: Vers une meilleure insertion professionnelle des jeunes. Paris: AFD.

\section{Notes}

Note 1. https://www.youtube.com/watch?v=zy5H3ZSTG-A\&feature=youtu.be

Note 2. https://www.youtube.com/watch?v=YqZDtfY9GQA

\section{Appendix A}

Table 2. Statistics analysis

\begin{tabular}{|c|c|c|c|c|c|c|c|c|c|c|c|c|c|}
\hline VariablelStatistique & $\begin{array}{c}\text { Nb. } \\
\text { d'observations }\end{array}$ & $\begin{array}{l}\mathrm{Nb} . \mathrm{de} \\
\text { valeurs } \\
\text { manquantes }\end{array}$ & $\begin{array}{c}\text { Somme } \\
\text { des } \\
\text { poids }\end{array}$ & $\begin{array}{l}\mathrm{Nb} . \mathrm{de} \\
\text { modalités }\end{array}$ & Mode & $\begin{array}{l}\text { Mode } \\
\text { (effectif) }\end{array}$ & Modalités & $\begin{array}{l}\text { Effectif } \\
\text { par } \\
\text { modalité }\end{array}$ & $\begin{array}{l}\text { Fréquence } \\
\text { par } \\
\text { modalité } \\
(\%)\end{array}$ & $\begin{array}{l}\text { Borne } \\
\text { inf. } \\
\text { des } \\
\text { freq. } \\
(95 \%)\end{array}$ & $\begin{array}{l}\text { Borne } \\
\text { sup. des } \\
\text { freq. } \\
(95 \%)\end{array}$ & $\begin{array}{l}\text { Proportion } \\
\text { par } \\
\text { modalité }\end{array}$ & $\begin{array}{l}\text { Borne inf. } \\
\text { des } \\
\text { proportion: } \\
(95 \%)\end{array}$ \\
\hline \multirow[t]{2}{*}{$\begin{array}{r}\text { Comment aviez-vous connu le } \\
\text { programme du CQP ou } \\
\text { formation duale ? }\end{array}$} & 30 & 0 & 30 & 2 & 1 & 28 & Par Mon patron & 28,000 & 93,333 & 84,407 & 100,000 & 0,933 & 0,84 \\
\hline & & & & & & & Une connaissance & 2,000 & 6,667 & 0,000 & 15,593 & 0,067 & 0,000 \\
\hline \multirow[t]{3}{*}{$\begin{array}{l}\text { Qu'est-ce qui vous motivait à } \\
\text { aller au centre ? }\end{array}$} & 30 & 0 & 30 & 4 & 5 & 15 & Se libérer des exigences de l'atelier & 2,000 & 6,667 & 0,000 & 15,593 & 0,067 & 0,000 \\
\hline & & & & & & & Connaissance explicite & 2,000 & 6,667 & 0,000 & 15,593 & 0,067 & 0,000 \\
\hline & & & & & & & $\begin{array}{r}\text { Curiosité et connaissance explicite } \\
\text { Curiosité - connaissance explicite et } \\
\text { soutien du patron }\end{array}$ & $\begin{array}{l}15,000 \\
11,000\end{array}$ & $\begin{array}{l}50,000 \\
36,667\end{array}$ & $\begin{array}{l}32,108 \\
19,423\end{array}$ & $\begin{array}{l}67,892 \\
53,911\end{array}$ & $\begin{array}{l}0,500 \\
0,367\end{array}$ & $\begin{array}{l}0,32 \\
0,19\end{array}$ \\
\hline \multirow[t]{2}{*}{$\begin{array}{r}\text { Quels étaient les avantages de } \\
\text { la formation que vous recevez } \\
\text { dans les centres ? en quoi est- } \\
\text { elle différente de la formation } \\
\text { en atelier? }\end{array}$} & 30 & 0 & 30 & 4 & 4 & 20 & Conditions de travail très favorables & 2,000 & 6,667 & 0,000 & 15,593 & 0,067 & $0,00 \mathrm{c}$ \\
\hline & & & & & & & $\begin{array}{r}\text { Apprendre de nouvelles pratiques } \\
\text { Conditions de travail très favorables et } \\
\text { apprentissage de nouvelles pratiques } \\
\text { Conditions de travail très favorables - } \\
\text { apprentissage de nouvelles pratiques et } \\
\text { travail en groupe }\end{array}$ & $\begin{array}{r}4,000 \\
20,000\end{array}$ & $\begin{array}{l}13,333 \\
66,667\end{array}$ & $\begin{array}{r}1,169 \\
49,798\end{array}$ & $\begin{array}{l}25,498 \\
83,535\end{array}$ & $\begin{array}{l}0,133 \\
0,667\end{array}$ & $\begin{array}{l}0,01: \\
0,498\end{array}$ \\
\hline \multirow[t]{2}{*}{$\begin{array}{l}\text { Comment enseignez-vous le } \\
\text { métier à vos apprenties? Votre } \\
\text { méthode est-elle différente de } \\
\text { ce que votre patronne faisait? }\end{array}$} & 30 & 0 & 30 & 2 & 1 & 19 & Oui & 19,000 & 63,333 & 46,089 & 80,577 & 0,633 & 0,46 \\
\hline & & & & & & & N'a pas encore d'apprentis & 11,000 & 36,667 & 19,423 & 53,911 & 0,367 & $0,19 \mathrm{c}$ \\
\hline
\end{tabular}

\section{Copyrights}




\section{Macrothink}

International Journal of Social Science Research

ISSN $2327-5510$ 2021, Vol. 9, No. 1

Copyright for this article is retained by the author(s), with first publication rights granted to the journal.

This is an open-access article distributed under the terms and conditions of the Creative Commons Attribution license (http://creativecommons.org/licenses/by/4.0/). 